\title{
New Environment-Friendly Approach for Textile Printing Using Natural Dye Loaded Chitosan Nanoparticles
}

\author{
A. Hebeish, A. A. Shahin, M. Rekaby and A. A. Ragheb \\ Textile Research Division, National Research Centre, \\ El-Behouth St., Dokki, Cairo, Egypt.
}

\begin{abstract}
T $\mathrm{N}$ the current work we present radially new approach for sustainable Itextile colouration. The approach involves loading of a natural dye such as Red Poppy dye, on a biopolymer like chitosan after being reinvented to chitosan nanoparticles through ionic gelation with sodium tripolyphosphate. Thus obtained coloured particles are used in printing of ramie fabrics. TEM shows that unloaded chitosan nanoparticles (8$20 \mathrm{~nm})$ have a very homogeneous morphology with quite uniform particle size distribution while dye loading causes increased size (100 $150 \mathrm{~nm}$ ) and multi-shape formation.

Salient feature is that the natural dye loaded chitosan nanoparticles proved technically feasible when applied in textile printing without conventional additive, there is no need for binders or mordents. The highest colour fastness (K/S) values for Red Poppy dye loaded on chitosan nanoparticles on the printed Rami fabric samples are obtained at $\mathrm{pH} \mathrm{9}$, under sonication at $30^{\circ} \mathrm{C}$ for $30 \mathrm{~min}$ using steaming or fixation method.
\end{abstract}

Keywords: Chitosan nanoparticles, Red Poppy, Dye loading, Ramie and Textile printing.

Calls for the use of natural dyes have been just one of the consequences of increased human safety and environmental awareness concerns ${ }^{(1)}$. Natural colorants or dyes derived from flora and fauna are believed to be safe since they are non-toxic, non-carcinogenic, sustainable and biodegradable natural resources $^{(2,3)}$. Plant natural dyes can be obtained from any part of the plant like leaves, fruits, seeds, flowers, bark root,... etc ${ }^{(4)}$. They have diversified use in textile colouration ${ }^{(5)}$ and functional finishing ${ }^{(6)}$, food coloration ${ }^{(7)}$, $\operatorname{cosmetics}^{(8)}$, dye-sensitized solar cells ${ }^{(9)}$, histological staining, ${ }^{(10)} \mathrm{pH}$ indicator ${ }^{(11)}$ and several other application disciplines ${ }^{(11,12)}$.

Red Poppy ${ }^{(13-16)}$ (Papaver rhoeas L.) is an annual plant species from the Papaveraceae family and it has a wide expansion area throughout the world. Red poppy is native to Europe, North Africa and temperature regions of Asia, and is naturalized in North and South America. Papaver rhoeas L. which covers the nature with its red flowers are used as vegetables in some regions while red flowers of the plant are consumed as syrup in others. Red poppy contains 
alkaloids including papaverine, rhoeadine, isorhoeadine, meconic acid and mokocyanin. Mucilage and tannnis are also present. Chromofore obtained from the Papaver rhoeas L. is merocyanine which is a derivative of the anthocyanins. Main molecular structures of the anthocyanidins present in Papaver rhoeas L. flowers are Aluminium complex of cyanidin-3-glucosid.

Recently, some researchers have used the impregnation of polymer surfaces with natural dyes for several applications ${ }^{(17,18)}$. Little information can be found on the use of the biopolymer chitosan in this consequence ${ }^{(19)}$.

Chitosan is a copolymer formed by units of 2-deoxy-N-acetyl-Dglucosamine and 2-deoxy-D-glucosamine joined through glycoside $\beta(1 \rightarrow 4)$ bonds, obtained from the alkaline deacetylation of chitin ${ }^{(20)}$. Due to the nature of its chemical configuration and its abundance. non-toxicity, hydrophilicity, and anti-bacterial properties, it has been employed in the preparation of films, gels and spheres, for a great variety of applications ${ }^{(21)}$. A factor which makes chitosan highly attractive is that it represents a renewable resource ${ }^{(22,23)}$.

Ramie $^{(24-27)}$ is a highly sustainable eco-friendly vegetable cellulosic fiber. Rami combines the feel and look of exclusive Italian fabrics with rustic natural materials.It is very strong and durable; 8 times stronger than cotton and even stronger when wet. Ramie is naturally resistant to bacteria, mould and mildew as well as light damage, rot or insect attack. It is one of the oldest recorded natural fibers, and has been found in the shrouds used to wrap Egyptian mummies.

Concerning our current work, many approaches have been undertaken to promote and advocate textile colouration using natural dyes. However, to our knowledge no work has been published so far in this regard. Conventionally, the use of binders, mordents and other additives during application of natural dyes in textile coloration detracts from their advantage as being natural. The matter has evoked our interest to innovate radially new colorants based on natural materials. The innovation indulged loading the natural dye, e.g. Red Poppy dye, on chitosan nanoparticles. Synthesis, characterisation, and application of this dye loaded chitosan nanoparticles are studied and conclusions reached are reported. It is envisioned that such new colorant and others to be generated would contribute much in the synthesis and application on natural dyes with respect to handling, safety, biodegradability and compatibility.

\section{Experimental}

\section{Materials}

Substrate

A plain woven fabric of ramie fibers (supplied from Tosco Co. No. 25, 44 warps per inch and 46 wefts per inch) was used. 
Thickening agent

High-viscosity sodium alginate was supplied by Ceca Kolloid Chemie, Paris, France and used at a concentration of $3 \%$.

Chemicals

- High molecular weight chitosan of M.W.10104, with a viscosity of 800,000cps (Aldrich).

-Urea, sodium hydroxide, ammonium hydroxide, ammonium chloride, sodium tripolyphosphate and acetic acid were of laboratory grade chemicals.

Dyes used

Red Poppy (Papaver rhoeas L.) flowers were gathered from cultivated land and road sides in Egypt. The dyes are then dried, milled and sieved before use.

\section{Methods}

Preparation of chitosan nanoparticles

Chitosan was dissolved at $0.5 \%(\mathrm{w} / \mathrm{v})$ acetic acid and the $\mathrm{PH}$ was raised to $\mathrm{pH}$ 4.6-4.8 with $10 \mathrm{~N} \mathrm{NaOH}$. Chitosan nanoparticles formed spontaneously up on addition of $1 \mathrm{ml}$ of an aqueous tripolyphosphate solution $(0.25 \% \mathrm{w} / \mathrm{v})$ to $3 \mathrm{ml}$ of chitosan solution under magnetic stirring. Size of nanoparticles was determined by using TEM $^{(28,29)}$.

Impregnation of chitosan microspheres with the natural dye curcuma

The chitosan nanoparticles were loaded with the dye by employing an impregnation method ${ }^{(30)}$. This method consisted of the dissolution of dye in buffer solution $\mathrm{NH}_{4} \mathrm{OH} / \mathrm{NH}_{4} \mathrm{Cl} \mathrm{pH} 5,7,9,11$ and the resulting solutions were filtered to remove any impurities. These solutions were then placed in contact with chitosan nanoparticles for $30 \mathrm{~min}$ at $30^{\circ} \mathrm{C}$, under ultrasonication while protected from light.

\section{Preparation of the printing paste}

The pastes used for application of the Red Poppy loaded chitosan nanoparticles as a pigment colour in printing Ramie fabrics have been prepared as follows:

\begin{tabular}{lc} 
Natural dyes powder & Y g \\
Thickener & $30 \mathrm{~g}$ \\
Urea & $40 \mathrm{~g}$ \\
Water & $\mathrm{Yg}$ \\
& \\
\hline Total & $1000 \mathrm{~g}$
\end{tabular}

Printing technique

All the pastes were applied to the fabrics through flat-screen printing technique. 


\section{Fixation}

After printing and drying, the printed goods were subjected to fixation either by steaming at $120^{\circ} \mathrm{C}$ for $15 \mathrm{~min}$ or thermofixation for $3 \mathrm{~min}$ at $160^{\circ} \mathrm{C}$.

\section{Washing}

Washing of the fixed printed goods is carried out as follows:

-Rinsing thoroughly with cold water and warm water.

-Washing with a solution containing 2 g/L Hostapal CVET (non-ionic detergent) for $15 \mathrm{~min}$ at $60{ }^{\circ} \mathrm{C}$.

-Rinsing with warm and cold water and finally air drying.

\section{Measurements}

\section{Colour measurements}

The colour strength of the printed samples expressed as $K / S$ was evaluated by reflectance technique ${ }^{(31)}$.

\section{Results and Dicussion}

The results of transmission electrom microscope of chitosan nanoparticles (Fig. 1) presented a very homogeneous morphology with quite uniform particle size distribution. The particle size diameters obtained were in the range of 8$20 \mathrm{~nm}$. The histogram showed high density of the particles in one area which indicates the uniformity of the nanoparticles obtained.

\section{Effect of type of fixation}

Table 1 shows the effect of the ratio of dye to chitosan nanoparticles on the colour strength expressed as K/S for printed Ramie fabrics.

The data of Table 1 show that ; regardless of the method of fixation used ; increasing the dye to chitosan ratio results in higher K/S values.

The data (Table 1) also show that the K/S for the fabrics printed and fixed via steaming is relatively higher than their corresponding samples printed and fixed via thermofixation. This may be due to the nature of the higher amount of moisture during steaming. The moisture facilitates the mobility of the dye molecules and increases the rates of its transfer from the printed film of the thickener to the fabric causing an increase in the K/S.

The work was further extended to investigate the best conditions for loading of Red Poppy dye on chitosan nanoparticles. Different samples have been prepared using dye: chitosan nanoparticles ratio of 25:15 at different $\mathrm{pH}$ values and using different time and temperatures for sonication. 

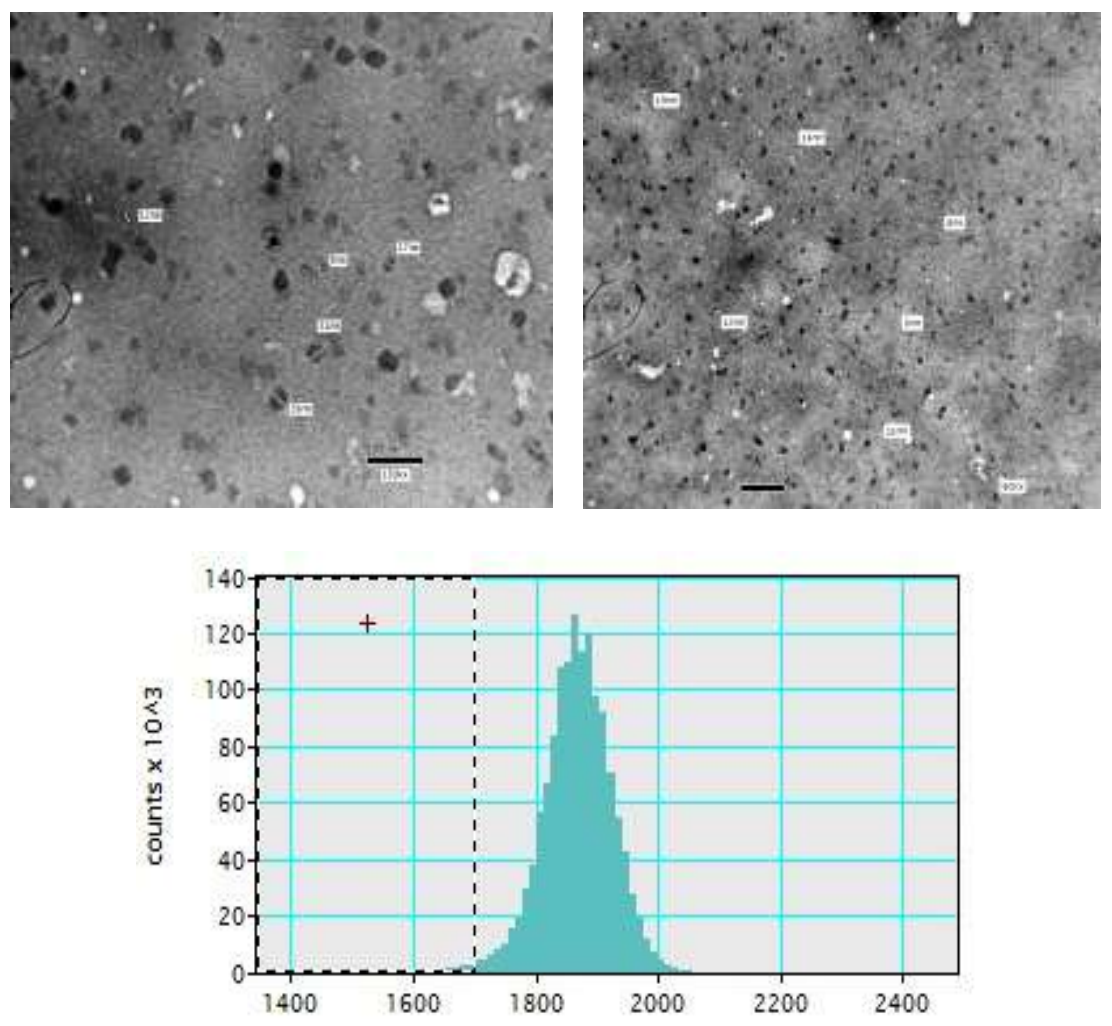

Fig. 1. Transmission electron microscope of chitosan nanoparticles.

TABLE 1. Effect of the ratio of Red Poppy dye to chitosan nanoparticle on the colouration properties of printed Ramie fabrics .

\begin{tabular}{|c|c|c|c|c|c|c|}
\hline $\begin{array}{c}\text { Dye : Chitosan } \\
\text { Ratio }\end{array}$ & Fixation & $\mathbf{L}$ & $\mathbf{a}$ & b & $\Delta \mathbf{E}$ & $\mathbf{K} / \mathbf{S}$ \\
\hline \multirow[t]{2}{*}{$25: 15$} & Steaming & 73.97 & 1.79 & 14.62 & 75.42 & 1.54 \\
\hline & Thermofixation & 75.66 & 0.1 & 15.37 & 73.20 & 1.3 \\
\hline \multirow[t]{2}{*}{ 20:20 } & Steaming & 75.15 & 1.53 & 11.12 & 75.99 & 1.22 \\
\hline & Thermofixation & 74.83 & -0.1 & 10.92 & 73.26 & 1 \\
\hline \multirow[t]{2}{*}{$15: 25$} & Steaming & 73.82 & 2.31 & 11.21 & 74.70 & 1.19 \\
\hline & Thermofixation & 70.46 & 0.3 & 10.66 & 70.20 & 0.9 \\
\hline
\end{tabular}

*The $\mathrm{K} / \mathrm{S}$ value of the blank sample is 0.7 


\section{Effect of pH of dye loading}

This study was carried out in the $\mathrm{pH}$ range of $5.0-11.0$. Since chitosan is soluble in acidic medium, below pH 5.5 chitosan nanoparticles swell forming a gel and its capacity to adsorb dye cannot be evaluated ${ }^{(32)}$. The adsorption of the dye increases in alkaline medium and it was observed that the optimum adsorption $\mathrm{pH}$ was 9.0 . Figure 2 clarified that, the highest $\mathrm{K} / \mathrm{S}$ values of the prints are brought into focus when dye loading on chitosan nanoparticles was affected at $\mathrm{PH} 9$.

The chromophore in Red Poppy dye is merocyanine. Solvatochromism, in which the dye solution changes its color as per the $\mathrm{pH}$ value or the polarity of the solvent, is one of the most well-known properties of the merocyanine dye. An earlier investigation found a red shift of the adsorption peak of merocyanines due to the deprotonation of the hydroxyl group of merocyanine molecule by changing the $\mathrm{pH}$ of the solution from $\mathrm{PH} 7$ to $\mathrm{PH} 10^{(16,33)}$.

Ramie fabrics printed using Red Poppy loaded chitosan nanoparticles impergenated at $\mathrm{pH} 9$ and 11 exhibit darker shade than those of $\mathrm{pH} 5$ and 7 (L,a,b, $\Delta \mathrm{E}$ values-Table 2). This may be attributed to the solvatochromism of merocyanine dyes.

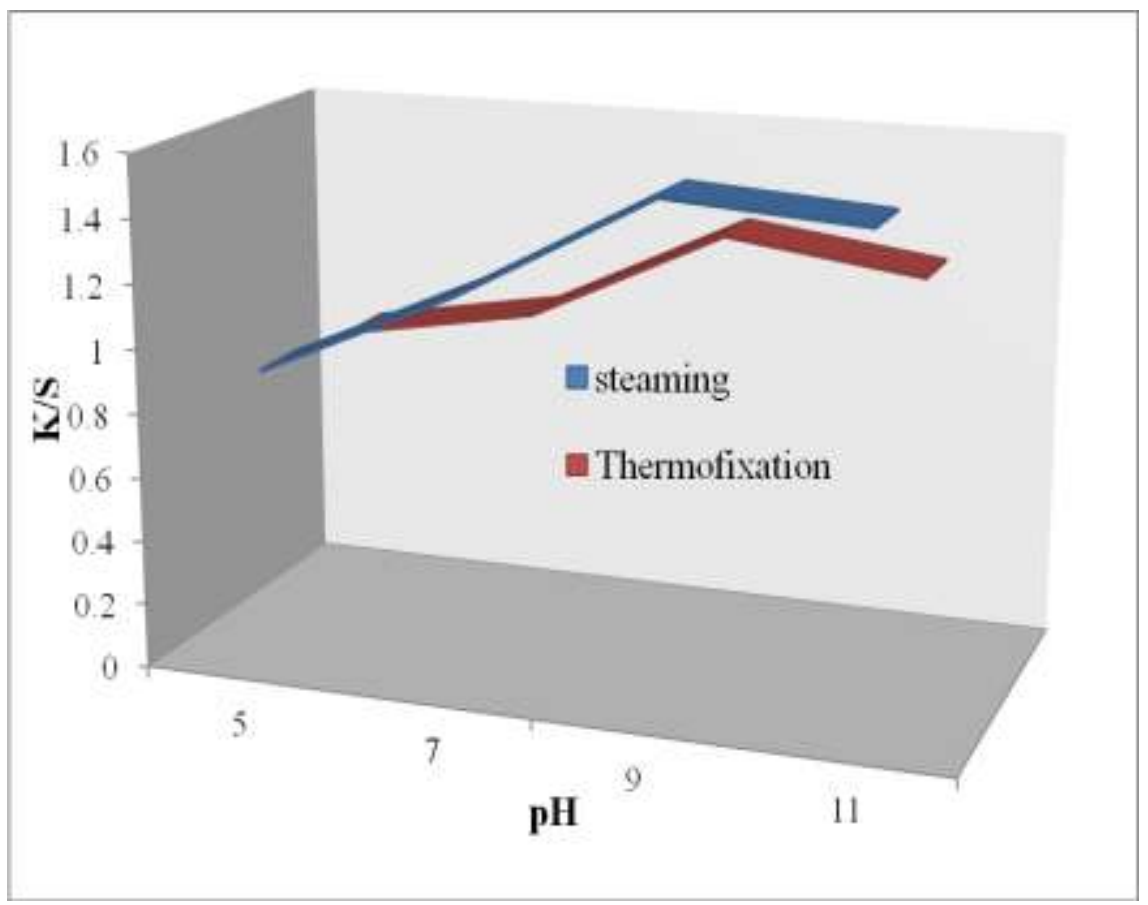

Fig. 2. Effect of pH of impregnation of chitosan microspheres with the natural dye Red Poppy on the K/S of the printed Ramie fabric.

Egypt. J. Chem. 58, No. 6 (2015) 
TABLE 2. Effect of pH of Red Poppy dye loading to chitosan nanoparticle on the colouration properties of printed Ramie fabrics .

\begin{tabular}{|c|c|c|c|c|c|}
\hline pH of dye loading & Fixation & $\mathbf{L}$ & $\mathbf{a}$ & b & $\Delta \mathbf{E}$ \\
\hline \multirow[t]{2}{*}{5} & Steaming & 70.11 & 0.22 & 10.52 & 69.33 \\
\hline & Thermofixation & 70.2 & 0.2 & 10.14 & 68.73 \\
\hline \multirow[t]{2}{*}{7} & Steaming & 72.23 & 0.11 & 10.88 & 73.70 \\
\hline & Thermofixation & 70.11 & 0.13 & 10.60 & 73.20 \\
\hline \multirow[t]{2}{*}{9} & Steaming & 73.97 & 1.79 & 14.62 & 75.42 \\
\hline & Thermofixation & 75.66 & 0.1 & 15.37 & 73.20 \\
\hline \multirow[t]{2}{*}{11} & Steaming & 73.2 & 1.66 & 14.77 & 74.33 \\
\hline & Thermofixation & 72.11 & 1.63 & 14.2 & 73.12 \\
\hline
\end{tabular}

Effect of time and temperature of dye loading

The effect of time and temperature of loading of Red Poppy dye on chitosan nano particles is illustrated in Fig. 3 and 4, respectively.

The data of Fig. 3 show that, regardless of the method of fixation, comparable $\mathrm{K} / \mathrm{S}$ values are obtained. On the other hand, samples printed using dye loaded chitosan nanoparticles at different time of sonication during loading display slightly higher values.

Figure 4 shows that increasing the temperature of dye loading bath over $30^{\circ} \mathrm{C}$ brought about lower $\mathrm{K} / \mathrm{S}$ values of Ramie fabric samples printed using the Red Poppy dye loaded chitosan nanoparticles. This may be attributed to the thermal degradiation of the natural dye.

Obviously, then, it may be stated that the best conditions for Red Poppy dye loading on chitosan nanoparticles are at $\mathrm{pH} 9$, using sonication at $30^{\circ} \mathrm{C}$. for $30 \mathrm{~min}$.

The morphological characteristics of dye loaded chitosan nanoparticles prepared at these conditions were examined using TEM technique. Figure 5 reveals that the size of dye loaded chitosan nanoparticles ranges from 100-150 nm. When compared to the unloaded chitosan nanoparticles (Fig. 1), an aggregation of distinctive single particles with clear joining boundries are observed. The increased size and multishape formation are due to the attachment of dye on the chitosan nanoparticles. 


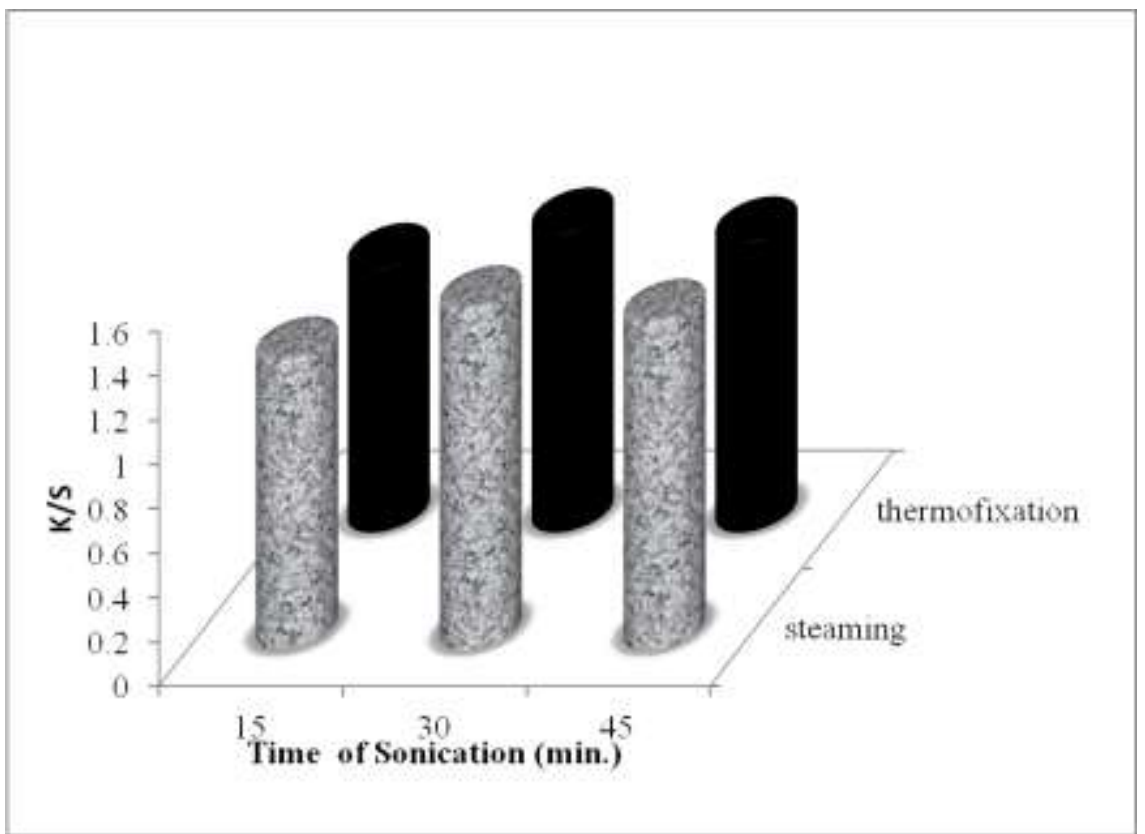

Fig. 3. Effect of time of sonication used for impregnation of chitosan microspheres with the natural dye Red Poppy on the K/S of the printed Ramie fabric .

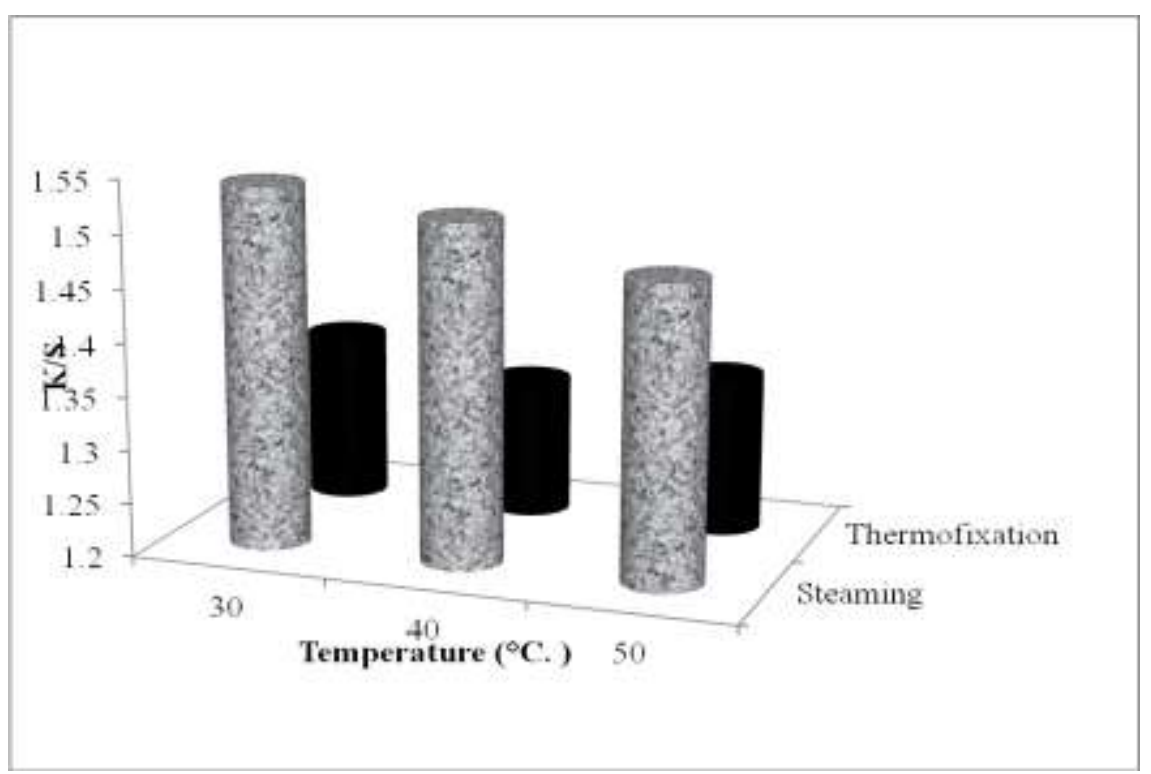

Fig. 4. Effect of temperature of sonication used for impregnation of chitosan microspheres with the natural dye Red Poppy on the K/S of the printed Ramie fabric .

Egypt. J. Chem. 58, No. 6 (2015) 


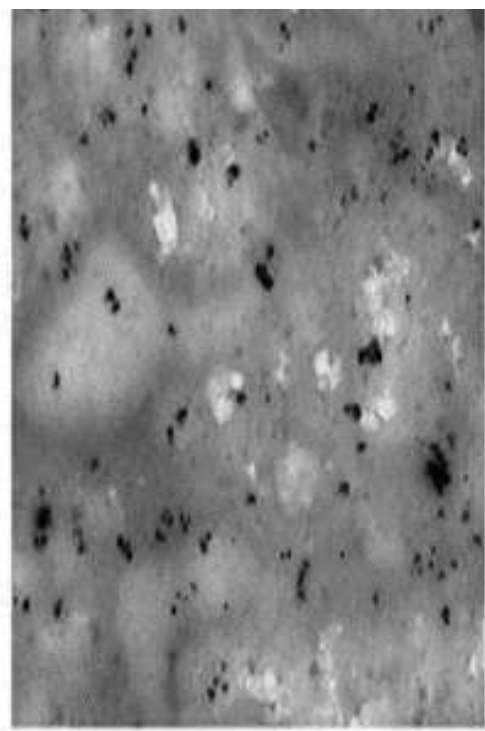

$500 \mathrm{~mm}$

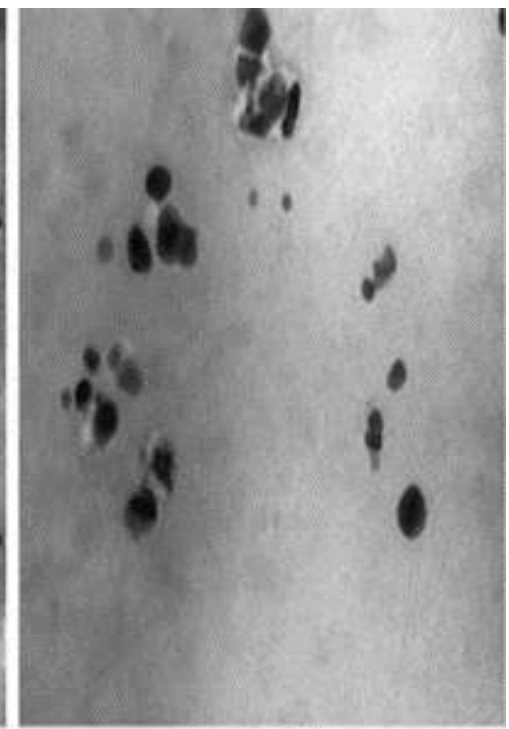

$\overline{100 \mathrm{~mm}}$

Fig.5. Effect of TEM image of the Red Poppy dye loaded on chitosan nanoparticles.

\section{Conclusion}

This paper describes the preparation of chitosan nanoparticles and its loading with natural dye Red Poppy to represent an eco- friendly approach to sustainable textile printing. The natural dye loaded on chitosan nanoparticles were applied on Ramie fabrics via pigment printing technique without the use of binder. The results obtained show that:

-The particle size diameters obtained were in the range of $8-20 \mathrm{~nm}$ for unloaded chitosan nanoparticles, while that of dye loaded chitosan nanoparticles ranges from 100-150 nm.

- Increasing the dye to chitosan nanoparticle ratio results in higher K/S values of the printed fabric regardless of the method of fixation used.

-The K/S for the fabrics printed and fixed via steaming is relatively higher than their corresponding samples printed and fixed via thermofixation.

- The highest K/S values of the printed Rami fabric samples have been obtained for Red Poppy dye loaded on chitosan nanoparticles at $\mathrm{pH}$ 9, using sonication at $30^{\circ} \mathrm{C}$. for $30 \mathrm{~min}$.

\section{References}

1. Chvan, R.B., Revival of natural dyes - a word of caution to environmentalists. Colourage, 42(4), 27 (1995). 
2. Mohammad Shahid, Shahid-ul-Islam and Faqeer Mohammad, Recent advancements in natural dye applications: A review. Journal of Cleaner Production 53, 310-331(2013).

3. Cristea, D. and Vilarem G., Improving light fastness of natural dyes on cotton yarn. Dyes Pigments, 70, 238-45 (2006).

4. Ansari, A. and Thakur, B.D., Extraction, characterization and application of a natural dye: the eco-friendly textile colorant. Colourage, 47(7), 15(2000).

5. Samanta, A.K. and Agarwal, P., Application of natural dyes on textiles. Indian J. Fibre Text. Res. 34, 384-399 (2009).

6. Gupta, D., Jain, A. and Panwar, S., Anti-UV and anti-microbial properties of some natural dyes on cotton. Indian J. Fibre Text. Res. 30, 190-195 (2005).

7. Delgado-Vargas, F., Jimenez, A.R. and Paredes-Lopez, O., Natural pigments: carotenoids, anthocyanins, and betalains d characteristics, biosynthesis, processing, and stability. Crit. Rev. Food Sci. Nutr. 40, 173-289 (2000).

8. Dweck, A.C., Natural ingredients for colouring and styling. Int. J. Cosmet. Sci. 24, 287-302 (2002)

9. Hao, S., Wu, J., Huang, Y. and Lin, J., Natural dyes as photosensitizers for dyesensitized solar cell. Sol. Energ. 80, 209-214 (2006).

10. Mishra, P.K., Singh, P., Gupta, K.K., Tiwari, H. and Srivastava, P., Extraction of natural dye from Dahlia variabilis using ultrasound. Indian J. Fibre Text. Res. 37, 8386 (2012).

11. Kuswandi, B., Jayus Larasati, T.S., Abdullah, A. and Heng, L.Y., Real-time monitoring of shrimp spoilage using on-package sticker sensor based on natural dye of curcumin. Food Anal. Method, 5, 881-889 (2012).

12. Zyoud, A., Zaatar, N., Saadeddin, I., Helal, M.H., Campet, G., Hakim, M., Park, D.H. and Hilal, H.S., Alternative natural dyes in water purification: anthocyanin as $\mathrm{TiO}_{2}$ sensitizer in methyl orange photo-degradation. Solid State Sci. 13,1268-1275 (2011).

13. Deepti Sankat and Nasreen Siddique, Studies on environment friendly dyes obtained from plants. Journal of Environmental Research and Development, 2 (3), January-March (2008).

14. Roy Osborne, Latin terms for pigments and dye-colours. 336-338, JSDC, 116 (2000).

15. Gheorghe-Virgil, Atodiresei, botanical resources of spontaneous and cultivated flora, with applications in the textile dyes industry. Lucrări Ştiinţifice . 54, Nr.1/2011, seria Agronomie.

16. Grace Frimpong, Investigating the suitability of hibiscus sabdariffa calyx extract as colouring agent for paediatric syrups, M.SC. Thesis in Pharmacy, Kwame Nkrumah University of Science and Technology (2008).

Egypt. J. Chem. 58, No. 6 (2015) 
17. Herek, L.C.S., Oliveira, R.C., Rubira, A. F. and Pinheiro, N., Braz. J. Chem. Eng. 23, 227-34 (2006).

18. Prachayawarakorn, J. and Kryratsamee, W., J. Appl. Polym. Sci. 100, 1169-75 (2006).

19. Vidyalakshmi, K., Rashmi, K.N., Kumar, T.M.P. and Siddaramaiah, M.P., J. Macromol. Sci. A 41,1115-22. (2004).

20. Kittur, F.S. and Tharanathan, R.N., Crit. Rev. Food Sci. Nutr. 43, 61-87 (2003).

21. Kumar, M.N.V.R., React. Funct. Polym. 46, 1-27 (2000).

22. Higuera-Ciapara, I., Valenzuela, I.F., Goycoolea, F.M. and Monal, W.A., Carbohydr. Polym. 56, 41-5 (2004).

23. Souza, T.C.R., Parize, A.L., Brighente, I.M.C., Fávere, V.T. and Laranjeira, M.C.M., J. Microencapsul. 22, 511-20 (2005).

24. Binita Baishya Kalita , Nabaneeta Gogoi and Sanghamitra Kalita, Properties of Ramie and its blends. International Journal of Engineering Research and General Science, 1(2), December ISSN 2091-2730 (2013).

25. Min SUN Hwang, Morphological differences between ramie and hemp: How these characteristics develop different procedures in Bast fiber production industries, Textile Society of America-12 Biennial Symposium-Lincoin. Nebraska-October 6-9, (2010).

26. Ajith Kumar, K. A., Sreekala, M. S. and Arun, S. , Studies on properties of biocomposites from Ecoflex/Ramie fabric-mechanical and barrier properties. Journal of Biomaterials and Nanobiotechnology, 3, 396-404 (2012).

27. Guang Hong Zheng, Hong Bin Fu and Guang Ping Liu, Application of rare earth as mordant for the dyeing of ramie fabrics with natural dyes. Korean Journal of Chemical Engineering, 28 (11), 2148-2155 November (2011).

28. Gouda, M. and Hebeish, A., Preparation and evaluation of $\mathrm{CuO} /$ Chitosan nanocomposite for antibacterial finishing of cotton fabric. Journal of Industrial Textiles, 39(3), 203-2012 (2010).

29. Wazed Ali, S., Rajendran, S. and Mangala Joshi, Synthesis and characterization of chitosan and silver loaded chitosan nanoparticles for bioactive polyester, Carbohydrate Polymers, 83(2), 438-446,10 January (2011).

30. Alexandre L. Parize, Melina Heller, Valfredo T. Fávere, Mauro C.M. Laranjeira, Inês M.C. Brighente, Gustavo A. Micke and Tereza C.R. Souza, Impregnation of chitosan microspheres with the natural dye curcuma. Lat. Am. J. Pharm. 28 (1), 19-26 (2009).

31. Judd, B.D. and Wyszecki, G., Colour in Business, Science, and Industry. $3^{\text {rd }}$ ed. London: John Wiley \& Sons (1975). 
32. Souza, T.C.R., Parize, A.L., Brighente, I.M.C., Fávere, V.T. and Laranjeira, M.C.M., J. Microencapsul. 22, 511-20 (2005).

33. Shim, T.K. Sung, J. and Kim, D., Photoluminescence characteristics of merocyanine dyes in ionic liquids. Journal of the Korean Physical Society, 48 (6), 1476 -1480 (2006).

(Received 7/10/2015;

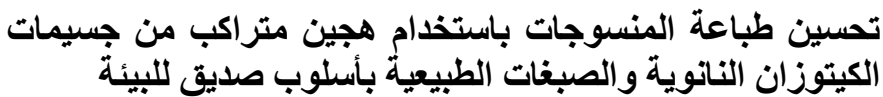

على على حبيش، أسماء على شاهين، منال مصطفى ركابى وأميرة عبدالمعطى

راغب اغلب

شعبة بحوث الصناعات النسجية - المركز القومى للبحوث - شارع البحوث - ماثب

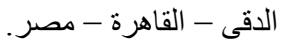

يقدم هـذا البحث اسـلوب جديد صـديق للبيئـة لطباعـة الأليـاف النسـجية الطبيعيـة

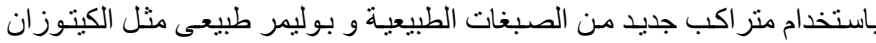

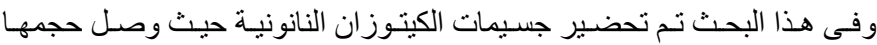

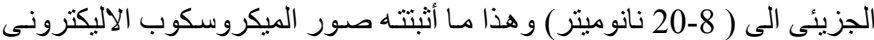

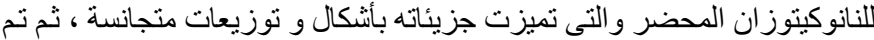

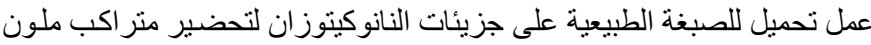

جديد من الكيتوزان و الصبغة ذو حجم جزيئى يتر اوح من (100-150 نانومينر ) .

ولقد تم أيضـا تطبيق هذا الهجين الملون في طباعـة ألياف الر امى بدون استخدام

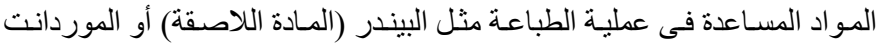

(المثبتات) وتم الحصول على عينات مطبو عة ذات قيم لونية مرتفعة.

Egypt. J. Chem. 58, No. 6 (2015) 